\title{
Network for Supporting Education of Foreign Children During Covid-19: Language Assessments as a ToOl for Promoting Community Integration
}

\author{
SAWADA Hiroko \\ University of Tsukuba, Japan \\ sawada.hiroko.gb@u.tsukuba.ac.jp
}

\author{
INOUE Rizu \\ Tsukuba Nihongo Support, Japan \\ tsukubanihongosapo@gmail.com
}

\begin{abstract}
The rising number of foreign residents in Japan has caused the number of children with foreign backgrounds in Japanese schools to increase. The present Japanese education system does not adequately support children whose mother language is not Japanese, and their educational problems have turned into social issues. We have conducted an action research project in collaboration with several schools and one university to determine how to develop a support system through online media that would soften the impact of the Covid-19 pandemic. We argue that language assessment is the key to driving the project and sharing the results of the assessment analysis with all project participants works effectively to promote collaboration between schools, families, and the university.
\end{abstract}

Keywords: online learning; foreign children; dialogic language assessment for Japanese as a second language; basic interpersonal communication skills; cognitive academic language proficiency

\section{Povzetek}

Naraščajoče število tujih prebivalcev na Japonskem je povzročilo, da se je število otrok tujega porekla v japonskih šolah povečalo. Sedanji japonski izobraževalni sistem ne podpira ustrezno otrok, katerih materni jezik ni japonski, in njihove izobraževalne težave so se spremenile $v$ socialna vprašanja. $V$ sodelovanju $z$ več šolami in eno univerzo smo izvedli akcijski raziskovalni projekt, da bi ugotovili, kako razviti sistem podpore prek spletnih medijev, ki bi omilil vpliv pandemije novega koronavirusa. Trdimo, da je jezikovno preverjanje ključnega pomena za vodenje projekta, in izmenjava rezultatov ocenjevalne analize z vsemi udeleženci projekta učinkovito spodbuja sodelovanje med šolami, družinami in univerzo.

Ključne besede: spletno učenje; otroci tujcev; dialoško ocenjevanje za japonščino kot drugi jezik; osnovne veščine medosebne komunikacije; kognitivno znanje akademskega jezika 


\section{Introduction}

Increasing economic globalization reflects in the rapidly increasing number of international migrant workers. This trend is not only observed in Europe but also in Asia, including Japan. Although the 2008 financial crisis caused a temporary decrease in the number of foreign residents in Japan, this number has again been increasing since 2012, reaching a record of 2,933,137 by the end of 2019. However, the outbreak of coronavirus diseasein 2019 (Covid-19) resulted in restrictions on foreigners' entry into the country, which caused the number of foreign residents in Japan to drop by $1.6 \%$ to $2,887,116$ by the end of $2020 .^{1}$

Along with Covid-19's effects on the influx of foreigners into Japan, other problems such as the social isolation of foreign migrant workers' families from their local communities have also become apparent. In this article, we focus on an associated issue, namely the education of children from foreign workers' families. We discuss the impact of the Covid-19 pandemic on the support systems for children of foreign migrant workers and provide an overview of the action research we conducted concerning this problem.

\section{Japanese language education system for foreign residents}

\subsection{Language education for foreign residents in Japan}

The number of foreign residents in Japan is about $2.3 \%$ of the total population, which is a low percentage compared to European countries; in some towns in Tokyo, Aichi, and Osaka Prefectures, however, the percentage is as high as in European countries, reaching $10 \%$ to $20 \%$ of the population. The rising numbers of foreigners who have settled down in Japan have, however, revealed that many foreign residents lack the ability to participate in the community.

Unlike countries such as the Netherlands, Sweden, and Germany, where the national government takes the initiative and is responsible for language education so that foreign residents can settle in the country and lead a full cultural life, there has been no Japanese language education for foreign residents at the national level in Japan. The Agency for Cultural Affairs (AOCA) began evaluating Japanese language education for "foreigners living in Japan" in 2008, and it has since 2010 proposed and published several standard curriculum plans, guidebooks, examples of teaching materials, proficiency assessments, assessments of execution, and handbooks. ${ }^{2}$

\footnotetext{
${ }^{1}$ This information comes from a survey by the Japan Immigration and Refugee Management Agency, https://www.isa.go.jp/en/publications/press/nyuukokukanri04_00018.html.

${ }^{2}$ Materials are available on the AOCA website https://www.bunka.go.jp/seisaku/kokugo_nihongo/kyoiku/nihongo_curriculum/.
} 
However, in the absence of a national policy for training language instructors and for securing financial resources, these efforts remain at the level of proposals and have not yet been disseminated throughout the country.

The Common European Framework of Reference for Languages (CEFR), published in 2001, is widely used in foreign language education and assessment around the world. It is, for example, used in the language education system guaranteed to immigrants in Germany.

The Japan Foundation released its 'JF Standards' in $2010^{3}$ based on the concepts of the CEFR. As with the CEFR, proficiency in Japanese is expressed in six levels $(A 1, A 2$, $B 1, B 2, C 1$, and C2), and can-do descriptors are presented for each level. The concept of proficiency-based language education is gradually becoming popular in Japan, and several textbooks based on this concept have been published. However, this philosophy is not yet widely understood by the general public, and it has not yet been applied to the public language education system guaranteed to foreign residents.

Given these circumstances, the Law on the Promotion of Japanese Language Education was promulgated and enforced in June 2019. This law states that all foreign residents, including children, should be guaranteed the maximum opportunity to receive Japanese language education, which is a responsibility of national and local governments. Consequently, Japanese local governments have started to work on creating a system to provide Japanese language education for foreign residents in cooperation with various stakeholders.

\subsection{Education of foreign children ${ }^{4}$ in Japan}

The number of children with foreign backgrounds concurrently rises together with the increasing number of adult workers that have settle in Japan. According to a 2019 survey by the Ministry of Education, Culture, Sports, Science, and Technology (MEXT), $4.4 \%$ or 5,023 of the 123,830 school-aged foreign children in Japan are enrolled in international schools, while $84.8 \%(96,370)$ are enrolled in compulsory-education schools. ${ }^{5}$

The MEXT compulsory-education program does not include a special curriculum for non-native speakers of Japanese, meaning that these children must learn the

\footnotetext{
${ }^{3}$ For a detailed explanation visit the Japan Foundation's website (https://jfstandard.jp/).

${ }^{4}$ The expression "foreign children" is often replaced by "children with foreign roots", "children whose mother tongue is not Japanese", or "children who need Japanese language instruction". In this paper, however, it is used as a term, in the same sense as "foreign students", which is an established term in the school education system by the Ministry of Education, Culture, Sports, Science and Technology.

${ }^{5}$ Results of the Survey on the Schooling Status of Foreign Children, published by MEXT in March 2020 (https://www.mext.go.jp/b_menu/houdou/31/09/1421568_00001.htm).
} 
language while concurrently adapting to Japanese school life. Foreign children in Japan consequently show comparatively high rates of non-attendance at classes or even nonenrollment in school, low rates of high-school enrollment, and high dropout rates, which is mainly due to children's insufficient Japanese language skills and their inability to adapt to school life (Kojima, 2016).

In 2014, the Enforcement Regulations of the School Education Law were amended, allowing compulsory-education schools to organize special-education programs to provide Japanese language instruction for foreign children. However, these programs have not become sufficiently widespread, mainly as a result of a shortage of teaching staff with the expertise to organize Japanese language acquisition programs.

\subsection{Community-based support systems and their limitations}

Recently, citizen volunteers have been mobilized to estimate the lack of Japaneselanguage instruction in public education. In many cases, non-profit organizations, international associations, and volunteer groups comprising pupils' parents help support Japanese language learning. Sometimes volunteers rent public spaces in communities and hold Japanese language classes after school; alternatively, volunteers collaborate with school teachers to establish Japanese language classes in schools. Many volunteers are not experts in Japanese language education but have years of involvement in local activities and experience working with children.

In the early 2020 the Covid-19 pandemic closed down public life and with it Japanese language classes for approximately four months. However, after schools reopened, it took a relatively long time for Japanese language classes to reopen, with some of them being suspended entirely because as a non-public services they exclusively depended on citizen volunteers.

To solve social problems in school education, it is important to secure local residents' cooperation; however, from the experience with the Covid-19 epidemic we can conclude that such an approach represents a weakness in times of emergency. Thus, new approaches are needed to create a sustainable education-support system for foreign children.

\section{Designing action research}

\subsection{Online Japanese language learning support}

\subsubsection{Collaborative project with a prefectural university}

The Law on the Promotion of Japanese Language Education, which went into effect in 2019, states that it is the responsibility of the national and local governments to 
enhance opportunities for Japanese language education for children. Ibaraki Prefecture, where the University of Tsukuba is located, started the Global Support Project in 2019 and has begun to work on building a system to support Japanese language education in elementary and junior high schools with the help of NPOs and other organizations.

As part of the Global Support Project, the University of Tsukuba, operating under the contract for the Ibaraki Prefectural Board of Education, commenced a model project in 2020 in which university students provide online learning support for foreign children. The original motivation was not the epidemic, but rather to create a support system for Japanese language instruction in suburban schools, which can be difficult for volunteers to access due to insufficient public transportation. Recently, students at the University of Tsukuba have become increasingly interested in the issues facing children, and numerous university students wanted to help foreign children with the Japanese language. However, the soft power of student volunteers cannot be fully utilized because of the difficulty in accessing suburban schools (Osada et al., 2021; Sawada et al., 2021).

This project aims to create a system in which educational effects are mutually circulated. Such a system would, first, help schools receive necessary educational support despite the insufficient Japanese language education resources in the area, and second, help universities to nurture citizens who could thereafter support the growing multiculturalism in Japan. The Covid-19 epidemic has increased the significance of online Japanese language support systems, as physical contact between people has been restricted.

\subsubsection{Training 'Japanese language supporters'}

Meetings between representatives of the program and school personnel began in June 2020. Nine children from two junior high schools in Ibaraki prefecture participated in this project. Some of these children had been living in Japan for only three months, while others had been born and raised in Japan. Many children had Filipino heritage, while others had Thai, Vietnamese, Pakistani, and Sri Lankan backgrounds. All were experiencing some form of learning difficulties.

Fourteen students from the University of Tsukuba participated in the program as Japanese language supporters. Their role was to help the children learn Japanese. Ten of the university students were majoring in Japanese language and culture, two of them education, one humanities, and one of the students majored disability science. Twelve of the fourteen students were also enrolled in teacher training courses to obtain their teaching licenses. All were at least second-year students, and all had taken introductory or specialized courses in Japanese language education. However, while four students had experience teaching Japanese in Japan or abroad, the other ten students were new to teaching Japanese. 
These students were trained in Japanese language instruction through a five-week university course (three hours per week) in July and August of 2020. The course had three goals for students, namely (1) to develop and stimulate emphatic attitude towards foreign children, (2) to design a class combining Japanese language learning and subject learning, and (3) to develop online teaching skills. During the course, the university students watched and discussed videos of interviews with Japanese language schoolteachers and volunteers to deepen their understanding of the difficulties foreign children face with. The students also participated in a workshop to create a 50-minute lesson plan where they practiced making class activities using mathematics as an example, and they learned how to use visual aids effectively using screen sharing in a video conferencing system.

The students started as Japanese language supporters in October 2020. From their homes, they connected with children from a junior high school via a Zoom online video conferencing system and conducted 50-minute sessions of Japanese language support three times a week over six months (October 2020-March 2021).

They prepared their own online materials by referring to the Marugoto textbook and changing contents to fit the children's daily life situations. The Japanese language supporters designed lessons based on the can-do descriptors necessary for daily life so that children could learn in a fun way. Although a high level of expertise is not needed to develop such teaching skills, a basic understanding of proficiency-based language teaching is necessary. For their support activities, the students were awarded university internship credit.

\subsection{Community cooperation linking schools, families, and universities}

Our primary concern about a study design was how to create an online support system that would stimulate a person-to-person interaction. We consequently developed a system which would deepen cooperation among all stakeholders that support children's education and monitor their growth: schools, families, and universities, as shown in Figure 1. 


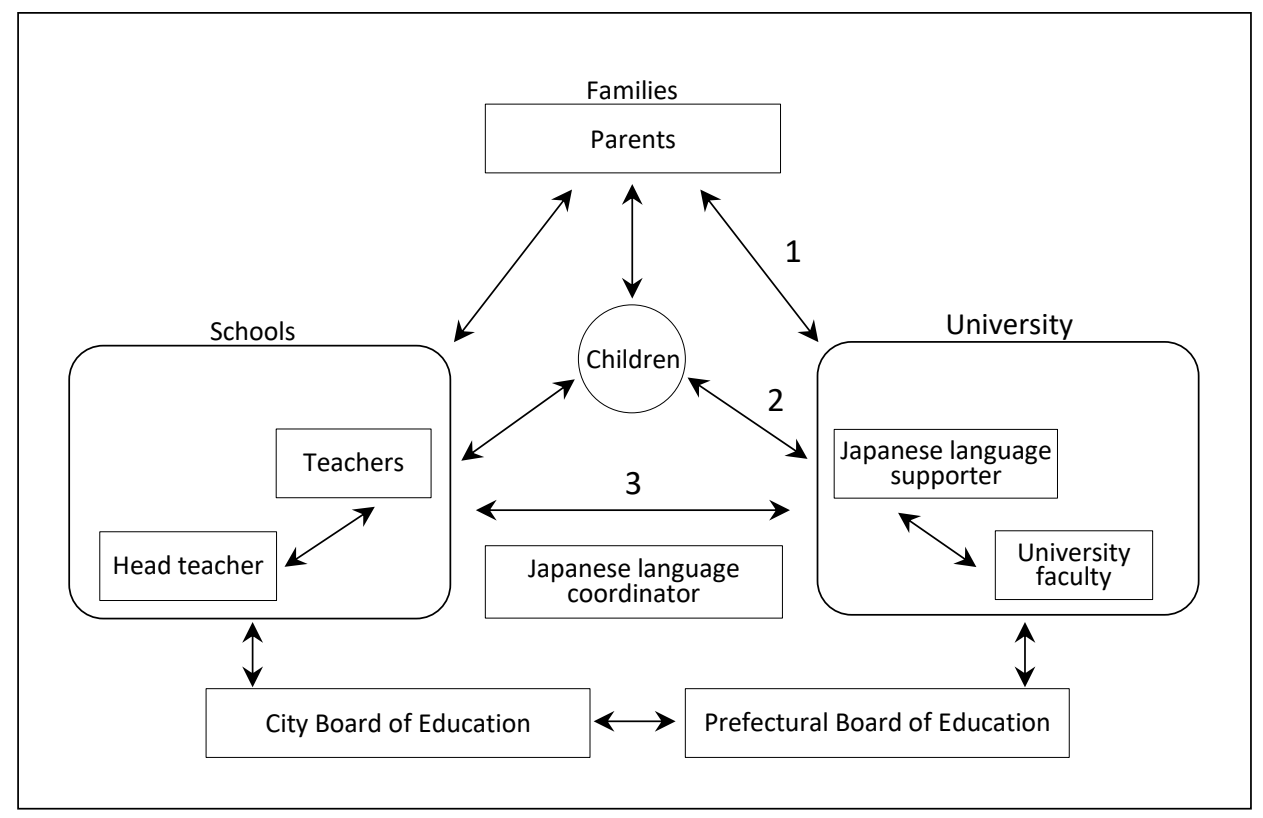

Figure 1: Community cooperation linking schools, families, and the university

The participants' roles in the project were defined as follows.

CHILDREN Non-native Japanese junior high school pupils who study three times a week with Japanese language supporters.

PARENTS Children's parents or guardians who supervise their learning at home.

JAPANESE LANGUAGE SUPPORTERS University students who have completed a five-week training course and provide Japanese language support to children.

UNIVERSITY FACULTY Professors who design and implement the project on behalf of the Prefectural Board of Education, and train and advise Japanese language supporters.

JAPANESE LANGUAGE COORDINATOR The liaison who coordinates stakeholders, implements Japanese language assessments, and develops support plans based on assessment results.

TEACHERS Junior high school instructors who set up equipment and supervize learning activities when Japanese language support is provided.

HEADTEACHER The administrator who oversees projects, teachers, and curriculum within the junior high school.

CITY BOARD OF EDUCATION The administrative group that supports junior high schools under the guidance of the Prefectural Board of Education. 
PREFECTURAL BOARD OF EDUCATION General director of this project, which provides guidance and budgetary support to the City Board of Education and the University.

\subsubsection{Briefings and interviews with children and parents}

Before commencing the Japanese language support program, we held a briefing session with children and their parents or guardians involved in the project. We explained the Japanese language program and emphasized that family support is also important for developing children's ability to live in Japanese society. After that, we conducted a semi-structured 30-to-60-minute interview with the parents to assess their readiness and needs, collecting information on language use at home, children's learning environments, and parents' beliefs and desires regarding their children's education and career paths. Based on the information obtained in interviews we developed the curriculum. For each child, interpretation and translation materials were prepared based on the education elements required.

\subsubsection{Japanese language supporters' roundtable with children}

After the five-week training and before the start of Japanese language support activities, the university students visited the school and had a two-hour exchange session with the children they would be teaching. The purpose of this meeting was to encourage self-disclosure through talking about daily life and to provide an opportunity for face-to-face interactions, which could promote mutual trust before the commencement of online learning support. The university students carefully listened to the children describe what they liked at school and what they found difficult, their opinions on learning Japanese and other subjects, and how they wanted to overcome those difficulties. Hearing the children's thoughts and feelings helped the supporters build relationships in which the children saw them as reliable companions rather than merely trainers in Japanese language instruction.

\subsubsection{Japanese language supporters' liaison meeting with school teachers}

To coordinate administrative matters between the school and university, we recruited a Japanese language coordinator. This coordinator was a specialist in Japanese language education and conducted Japanese language assessments for children. Liaison meetings during and at the end of the semester involved the school, university students, and the Japanese language coordinator. At these meetings, the coordinator shared the results of the assessments, while the Japanese language supporters discussed the children's progress, and the school teachers provided information about the school environment. This setting, where the children's condition and growth could be shared, prevented the support program from becoming a closed online space. The 
meetings also allowed the university students to connect with the local community and experience the responsibility and joy of participating in educational social activities.

\section{Language assessment and enriched community collaboration}

\subsection{Background, features, and structure of the DLA}

Cummins (1979) differentiated language proficiency into basic interpersonal communication skills (BICS), used in everyday communications, and communicative academic language proficiency (CALP), related to cognitive and learning abilities. According to Cummins, CALP is the specialized language used in a workplace, business, economics, science, politics, and others. In school, CALP is needed to understand contents in learning situations correctly and to express one's own opinions. Krashen and Brown (2007) showed that CALP consists of two abilities, knowledge about language and knowledge about the subject matter, and positioned language acquisition for acquiring knowledge of a subject as a necessary tool for human independence and the primary goal of education.

For children in Japan to acquire the language skills necessary for academic learning, they must receive systematic Japanese language instruction. Most foreign children can acquire Japanese BICS in approximately two years of schooling, while age-equivalent CALP takes over five years (Nakajima, 2010). Among many foreign children in Japan, even those born there or who have lived there for a long time, Japanese language development is often limited to BICS (Sakurai, 2018). Children's language operational and thinking skills are affected in many ways by their mother tongue, actual age, age of their arrival to Japan, and length of stay. Therefore, we chose not to use a standardized test, such as a paper or group test, but an interactive performance test to determine each child's potential.

To assess the children's Japanese language skills, we used the dialogic language assessment for Japanese as a second language (DLA) developed by MEXT (2014). The DLA can be used to assess not only daily conversational ability in Japanese but also Japanese language proficiency in the context of academic studies; it can also be used to identify the kind of learning support the child needs. The DLA is also unique in that the process of administering the test represents an opportunity for learning.

The DLA comprises six assessment tools: introductory conversation, vocabulary check, speaking, reading, writing, and listening. The introductory conversation and vocabulary check are always conducted first, as these are used to determine whether the subsequent skill-specific tests can be administered. The four skill-based tests, speaking, reading, writing, and listening, should not be administered together but at times that suit the child's situation. After these assessments, the child's Japanese 
language ability is ranked in terms of six stages, referred to as the Framework of reference for Japanese as a second language (Table 1).

Table 1: Framework of reference for Japanese as a second language

\begin{tabular}{|c|c|}
\hline 1 & Has begun learning the elements of the Japanese language required for school life \\
\hline 2 & $\begin{array}{l}\text { Has some familiarity with the elements of the Japanese language required for } \\
\text { school life, but requires assistance }\end{array}$ \\
\hline 3 & $\begin{array}{l}\text { Can understand daily-life-related topics and can, with assistance, participate in } \\
\text { class activities to some extent }\end{array}$ \\
\hline 4 & $\begin{array}{l}\text { Can understand daily-life-related topics and can participate in-class activities to } \\
\text { some extent }\end{array}$ \\
\hline 5 & $\begin{array}{l}\text { Can understand topics related to academic subjects and can participate in class } \\
\text { activities with some support }\end{array}$ \\
\hline 6 & $\begin{array}{l}\text { Can understand topics related to academic subjects and can actively participate in } \\
\text { class activities }\end{array}$ \\
\hline
\end{tabular}

There are no special qualifications required to conduct the DLA and analyze its results, and all the implementation and evaluation methods are available on the MEXT website. Training videos are also available and provide a clear overview of the assessment process and points to consider.

These assessments can be implemented as (1) diagnostic assessments performed at the beginning of Japanese language learning support to assess children's Japanese language ability, (2) formative assessments conducted during Japanese language learning support to understand the children's learning process and identify areas of weakness, and (3) summative assessments performed at the end of the school year to forecast the children's future abilities and inform teaching plans for the next term.

To ensure a comprehensive understanding of each child's actual situation and create appropriate instructional plans, it is necessary for all parties involved in the support program to use a common assessment tool. If all stakeholders interact with the child on a daily basis, it is possible to use non-assessment-based methods, such as multifaceted observations of the child's language development while they perform daily activities; such methods have been found to be relatively effective (Furukawa et al., 2016). However, when stakeholders outside of the school such as university students, university faculty, and boards of education are involved, as was the case in this program, the DLA represents a very effective tool for sharing the challenges that children face and for building a support system in which all involved work to achieve a common goal. 


\subsection{Visualizing the challenges children experience}

If stakeholders are not aware of the difficulties the children face, learning support will not be successful. Children participating in our program seemed to enjoy school life generally, talking with friends and actively participating in physical education and music time. Despite this, however, school teachers felt that the children needed some support because their academic test scores were low. The DLA is helpful in this regard because it defines the Japanese language ability of each child individualy and provides suggestions about the kind of support they need.

The DLA speaking assessment includes a basic task to measure the child's ability to answer questions regarding daily life; an interactive task to measure their ability to lead a conversation, such as "asking a friend to play soccer" or "politely apologizing for breaking a window"; and a cognitive task to measure their ability to talk about specific topics, such as "explaining the causes of global warming." Table 2 shows an excerpt from a Tagalog-speaking student's DLA evaluation sheet for speaking, conducted about one year after this student came to Japan from the Philippines. The Japanese language coordinator carried out the assessment and analyzed and evaluated the results.

Table 2: A student's DLA (speaking) evaluation sheet

\begin{tabular}{|c|c|c|}
\hline & $\begin{array}{l}\text { Pct of correct } \\
\text { answers }\end{array}$ & Questions the child could not answer \\
\hline $\begin{array}{l}\text { Introductory } \\
\text { conversation } \\
\text { (16 questions) } \\
\end{array}$ & $88 \%$ & $\begin{array}{l}\text { What do you do with your friends? } \\
\text { What do you like about Japanese schools? }\end{array}$ \\
\hline $\begin{array}{l}\text { Vocabulary check } \\
\text { (55 questions) }\end{array}$ & $75 \%$ & $\begin{array}{l}\text { Eyelashes, lips, (cow) horns, (cat) whiskers, branches, } \\
\text { roofs, drawers, erasers, maps, drivers, doctors, } \\
\text { firefighters, wings, wear }\end{array}$ \\
\hline $\begin{array}{l}\text { Basic task } \\
\text { (18 questions) } \\
\end{array}$ & $100 \%$ & None \\
\hline $\begin{array}{l}\text { Interactive task } \\
\text { (11 questions) }\end{array}$ & $27 \%$ & $\begin{array}{l}\text { Card (4) B/ } \\
\text { (i) Ask a friend. } \\
\text { Card (5) } \\
\text { (i) Introduce yourself. } \\
\text { Card (6) Invitation to friends } \\
\text { (i) Start a conversation. } \\
\text { (ii) Extend an invitation. } \\
\text { (iii) Consult and decide the time and place. } \\
\text { (iv) End the conversation. } \\
\text { Card (7) } \\
\text { (i) Describe what happened or what you did. } \\
\text { (ii) Apologize. }\end{array}$ \\
\hline
\end{tabular}




Cognitive task $\quad 17 \% \quad$ Card (11) Global warming (See an illustration of the
(1), (2)
$\begin{aligned} & \text { (9 questions) } \\ & \text { (i) Describe why the earth is crying. } \\ & \text { (ii) State what we can do to stop global warming. } \\ & \text { (iii) Explain the factors that contribute to global warming. } \\ & \text { Card (12) Earthquake } \\ & \text { (i) Have you ever been in an earthquake? Describe what } \\ & \text { happened to you. } \\ & \text { (iii) Explain the mechanism of the earthquake. }\end{aligned}$

In the evaluation sheet shown in Table 2, the most striking feature is that the child could answer all questions in the basic task correctly, while only $27 \%$ of those in the dialogue task. This means that the student was able to have short conversations with her friends in the context of school life but was unable to communicate independently to initiate a dialogue and build a relationship. This difficulty would have been overlooked if the child was only observed having happy conversations with her friends. Additionally, in the cognitive task, she answered only $17 \%$ of the questions correctly, which indicates that she did not have enough vocabulary to learn the subject matter and compose a discourse on it.

We administered the DLA to all nine children and completed an evaluation sheet for each. We shared these results with the teachers at the children's schools. We ensured that the teachers understood the DLA's composition and purpose, and carefully explained how to interpret the results. The following three cases feature comments made by school teachers after they had examined their pupils' DLA results:

- Case 1: The headteacher at the school said, "I thought she had a better understanding of the Japanese language because she usually understands the teachers' instructions and can work with her friends in school, but now I see that this behavior is a result of her strong ability to understand situations, and not her language ability."

- Case 2: Another child's homeroom teacher said, "I see; that's right, I was wondering what I could do to help him, because he can usually converse easily, but cannot write essays." This linked the DLA analysis to her usual observations of the child.

- Case 3: The headteacher at another school mentioned how the assessments had influenced her to change her teaching approach: "Now, when I explain something to my children, I try to think of the best way to communicate, and I check that they understand the words that describe the key details."

Analysis of these responses from the school teachers showed that the DLA had three effects: (1) teachers noticed weaknesses in the children's language ability that 
had previously been obscured, (2) they began to understand the reasons for certain language weaknesses they had observed but could not explain, and (3) once they had obtained an accurate understanding of the children's difficulties, they began to think of better ways to teach.

In this way, the Japanese language coordinator's assessments helped stakeholders define the children's difficulties; this led the schools in our project to develop an understanding of the importance of Japanese language learning support and greatly contributed to the creation of a strong relationship of trust between the university and the school.

\subsection{Curriculum rationale and clear guidelines for support}

The DLA also helped strengthen cooperation among the Japanese language supporters. Three university students formed a team and took turns providing Japanese language support for each child, with each supporter giving one of the three lessons provided each week. Team meetings, in which they discussed the contents of the lessons for the children were held online weekly.

An important part of this process was the children's Japanese language support plan. The Japanese language coordinator conducted the DLA, wrote an evaluation sheet, and developed a Japanese language support plan for each child. As shown in Figure 2, the Japanese language support plan was based on the results of the DLA, highlighted the elements to be prioritized, and provided a timeline and curriculum for future support.

\begin{tabular}{|c|c|c|c|}
\hline \multicolumn{4}{|l|}{ Student name } \\
\hline Japanese ability & $\begin{array}{l}\text { Implemented on Monday, Sep } 28,2020 \\
\text { (DLA/speaking). It was judged that the } \\
\text { subject was at stage } 3 \text { on the JSL } \\
\text { evaluation reference scale. }\end{array}$ & $\begin{array}{l}\text { JSL } \\
\text { evaluation } \\
\text { reference } \\
\text { scale } \\
\end{array}$ & \begin{tabular}{|c} 
Speaking \\
ability \\
3
\end{tabular} \\
\hline $\begin{array}{l}\text { Support priority } \\
\text { items }\end{array}$ & \multicolumn{3}{|c|}{$\begin{array}{l}\text { - I can relay a rich and cohesive story, providing explanations, reasons, } \\
\text { and opinions. } \\
\text { - I can compose paragraphs using both simple and complex sentences. } \\
\text { - I can select vocabulary suitable for the topic and content and use it } \\
\text { correctly. (Including vocabulary concerning academic subjects) }\end{array}$} \\
\hline
\end{tabular}




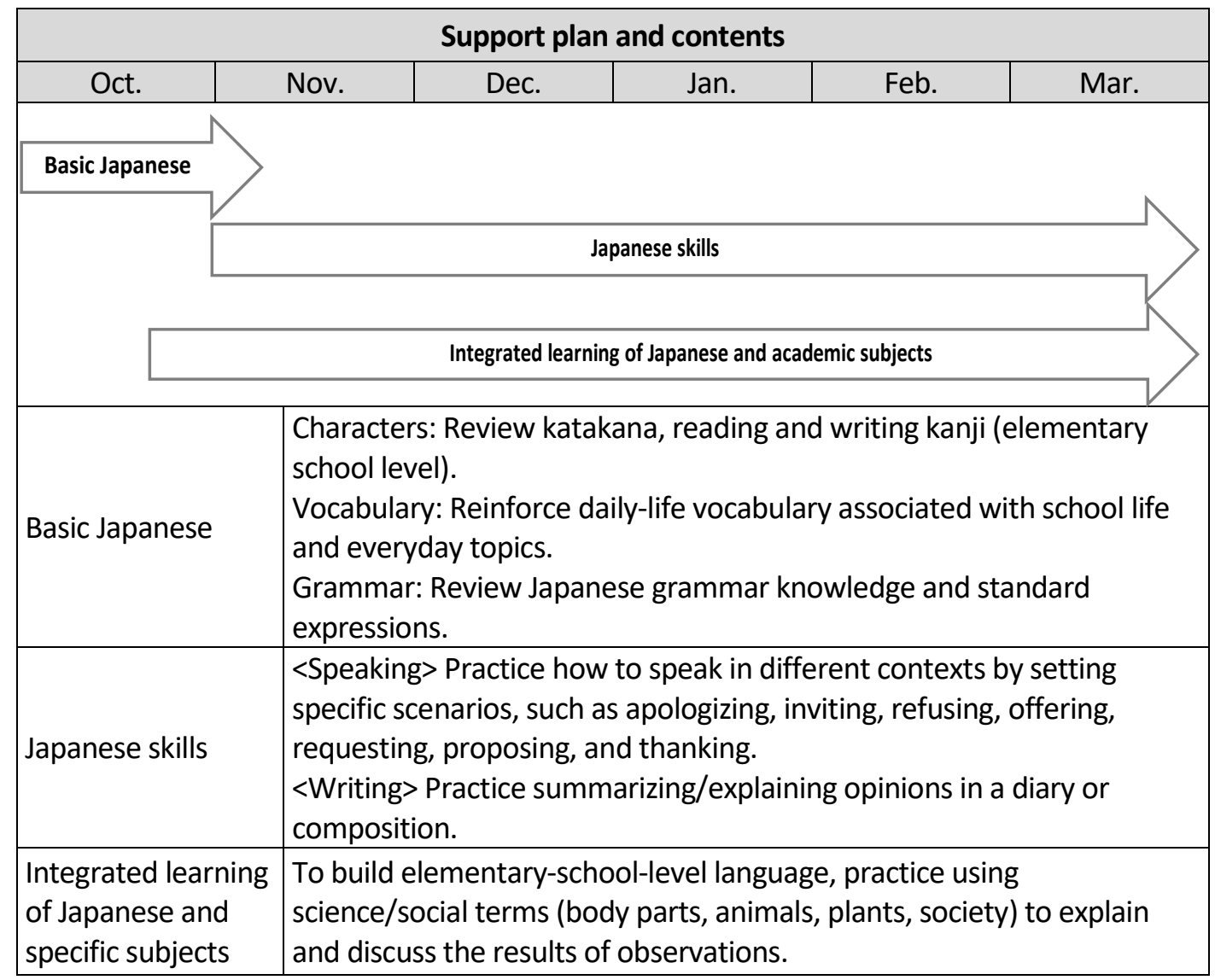

Figure 2: Japanese language support plan

The child whose DLA analysis is presented in Figure 2 was capable of having short conversations involving single-sentence answers but had difficulty initiating dialogue and communicating coherently without assistance. Therefore, the focus of the support was to teach the child how to combine multiple sentences into a coherent conversation based on a Japanese language curriculum that included opinion-writing practice and dialogue practice for situations such as "inviting" and "apologizing" (elements in which, according to the DLA, the child experienced difficulties). Additionally, as the child had not fully developed CALP and was unable to explain topics related to academic subjects, the plan commenced with exercises aimed at improving understanding of academic language to help integrate Japanese language study with academic subject study.

The university students who provided Japanese language support to the children in this project had different levels of experience in teaching Japanese, and some were teaching Japanese for the first time. Understanding children's difficulties does not automatically translate into being able to create a suitable support curriculum immediately, and it was helpful to have a Japanese language coordinator to outline individualized support plans. Further, it iwas important that Japanese language supporters had a good understanding of both the DLA evaluation sheet, which 
represents the rationale for the curriculum, and the individual support plan, which provides specific guidelines for support. We believe that the understanding of both elements among our Japanese language supporters allowed them to collaborate as a team and effectively implement this project.

\subsection{Formative assessment: sharing the joy of children's growth}

In this project, the Japanese language coordinator conducted DLAs every 10 weeks to provide regular data regarding the children's level of Japanese. The DLA as a formative assessment had a positive impact on the children, on their Japanese language supporters, on the teachers in schools, and on each school as a whole.

The DLA provides an assessment of children outside the classroom, and children who score low in subjects can monitor their progress through changes in their DLA results. We have noticed that the accumulation of such small successes can foster a positive attitude toward the DLA: with the help of their Japanese language supporters, the children themselves tried to prepare for their DLAs to achieve better results. The effectiveness of such assessments was also noted by Shimada (2014) in her implementation of the oral proficiency interview test.

The formative assessment provided through the DLA also motivated Japanese language supporters. Although it is sometimes difficult to measure a child's progress when providing daily learning support, the DLA results obtained at 10-week intervals afforded a visualization of each child's progress, which helped the Japanese language supporters maintain a positive attitude. The DLAs were an effective means of sharing the joy associated with observing the children's growth.

Also, school teachers improved their ability to monitor children's language skills. We conducted questionnaires and interviews with school teachers before, during, and at the end of the program. Before the program started, teachers completed a questionnaire and semi-structured interviews about their subjective assessment of the children's Japanese language skills. Many of them reported measuring the children's Japanese language ability based on how many kanji they could write. Although reading and writing kanji requires the cognitive ability to understand and use academic vocabulary, measuring children's Japanese language ability simply by considering their ability to write kanji represents a somewhat superficial approach.

In contrast, feedbacks from teachers represented a diversity of perspectives at the end of a semester. Teachers stated that they were better able to explain their thoughts and feelings, and also that the children were able to communicate their thoughts to others and understand their thoughts as well. Rather than judging writing based on the number of kanji, one teacher pointed out that children who used to be reluctant to write essays have grown up to be able to write coherent sentences. The feedback suggests that teachers started to assess multiple aspects of the children's Japanese 
language ability, including their use of vocabulary to explain abstract concepts, their ability to construct long utterances in discourse contexts, their cognitive ability to summarize thoughts and ideas, and, most importantly, their willingness to speak. As reported by Kawakami (2011), conducting the assessments may have provided an opportunity for the adults involved in the support program to review and develop their views on language ability.

Our program had a ripple effect on the schools. The teachers were delighted to see the children's eyes light up and their smiles become brighter through this project. Formative assessments also helped the teachers see how language development enriched children's friendships and school experiences. The headteachers at both schools involved in this project told us that they now have more time to discuss Japanese language support among their teachers, that they have realized once again the importance of the presence of the local university, and that they hope to continue this project in collaboration with the university.

\section{Conclusions and future development}

The challenges of language support for foreign residents in Japan, especially for children, stem from a lack of professionals who could provide such support in schools and communities. The system relies on volunteers, but face-to-face support has been hampered during the Covid-19 pandemic. Our action research in this joint project between Ibaraki Prefecture and the University of Tsukuba trained university students to become online Japanese language supporters for junior high students whose primary language was not Japanese.

Language assessment through the DLA was essential in driving this project forward. The DLA made the difficulties that children were experiencing visible, which enabled the stakeholders to understand and optimize learning plans for each child individually. The DLA as a formative assessment was very effective for the children, for their supporters, for the school teachers, and the schools as a whole.

The results obtained through our action research show us two challenges for a more prosperous regional cooperation in the future.

The first challenge concerns the types of experts we need to train. Opportunities for foreign children to get involved with local volunteers are important and effective in helping youngsters to become autonomous citizens in their communities. However, systematic Japanese language education is necessary for non-native speakers to acquire cognitive academic language proficiency, and this requires people with basic knowledge of second language education to provide day-to-day support. In addition, there is a need for more highly qualified professionals who can assess children, plan teaching, and give appropriate advice to Japanese language supporters and school 
teachers. In particular, the results of the assessments need to be shared with all stakeholders to elicit fully effective support systems. Assessors must act as coordinators between schools, families, and Japanese language supporters. Thus, we argue that it is necessary to train Japanese language supporters with basic knowledge and Japanese language coordinators with more specialized knowledge. In order to develop such professionals, we need educational designs involving university students, and universities that agree that training and social contributions are mutually beneficial.

The second challenge is the dissemination of the language. The DLA is designed to be conducted face-to-face; however, in this project, as a result of the Covid-19 pandemic, we conducted it online (except for the first assessment). It is therefore necessary to compare online and face-to-face implementation and verify their effectiveness. This far we have been able to implement speaking and writing DLA assessments without any major problems. If a certain level of quality can be maintained even in the online medium, conducting professional assessments may be possible in areas where there are no specialists or where it is difficult to dispatch specialists. This will contribute to the spread of high-quality Japanese language learning support throughout the region.

\section{Acknowledgments}

This work was supported by JSPS KAKENHI under Grant 19 K00642 and JSPS KAKENHI under Grant 20K00696. We would like to express our sincere gratitude to all who contributed to the Ibaraki Global Support Project.

This project has been reviewed and approved by the Ethics review committee in the Humanities and Social Sciences of the University of Tsukuba regarding the protection of children's human rights and personal information (September 2020). We have fully explained the project to the children, their guardians, and school teachers in advance, and have obtained their consent for research cooperation and publication of research results.

\section{Abbreviations}

BICS Basic interpersonal communication skills

CALP Cognitive academic language proficiency

Covid-19 Coronavirus disease 2019

DLA Dialogic language assessment for Japanese as a second language

MEXT Ministry of Education, Culture, Sports, Science and Technology 


\section{References}

Cummins, J. (1979). Cognitive/academic language proficiency, linguistic interdependence, the optimum age question and some other matters. Working Papers on Bilingualism, 19, 121-129.

Furukawa, A., Koike A., Osawa, S., Ishihara, G., Ito, R., Sakamoto, K., Sato, Y., \& Taguchi, K. (2016). The development of Nihongo Step: A framework for Japanese language assessment for foreign students. Journal of Center for International Education and Research, Gunma University, 15, 49-62.

Kawakami, I. (2011). "Idō suru kodomotachi" no kotobano kyōikugaku. Tokyo: Kuroshio Publishers.

Kojima, Y. (2016). Gaikokujin no shūgaku to husyūgaku; syakai de "mienai" kodomotachi. Osaka: Osaka University Press.

Krashen, S., \& Brown, C. L. (2007). What is academic language proficiency? STETS Language \& Communication Review, 6(1), 1-5.

http://www.sdkrashen.com/content/articles/krashen_brown_alp.pdf

Ministry of Education, Culture, Sports, Science and Technology. (2014). Dialogic language assessment for Japanese as a language. https://www.mext.go.jp/a_menu/shotou/clarinet/003/1345413.htm

Nakajima, K. (2010). Maruchi ringaru kyōiku eno syōtai: gengo shigen toshiteno Nihonjin • gaikokujin nensyōsya. Tokyo: Hitsuji Syobo.

Osada, Y., Matsusaki, H., Sawada, H., Iriyama, M., \& Yoshida, T. (2021). Analysis of "certificate program for the development of Japanese language learning supporters" within the University of Tsukuba. Bulletin of Institute of Education University of Tsukuba, 45(2), 1-13.

Sakurai, C. (2018). Gaikoku ni Rūtsu wo motsu kodomono Bairingaru dokusyoryoku no hattatsu. Osaka: Osaka University Press.

Sawada, H., Matsuzaki, H., \& Iriyama, M. (2021). Issues concerning support for foreign students in Tsukuba City and educational cooperation with local communities. Journal of Japanese Language Teaching, 36, 23-32.

Shimada, K. (2014). Teijyū gaikokujin nitaisuru ōdanchosa de miete kita koto: OPI wo tōshite "mizukara no koe wo hassuru koto" wo mezasu. Journal of the Japanese Association of Language Proficiency, 2, 30-49. 